\title{
Advances in dermoscopy for detecting melanocytic lesions
} Andrea Gulia $^{1,2}$ and Cesare Massone ${ }^{2 *}$

\author{
Addresses: ${ }^{1}$ Department of Dermatology, University of L'Aquila, L'Aquila, Italy; ${ }^{2}$ Department of Dermatology, Medical University of Graz, \\ Graz, Auenbruggerplatz 8, A-8036 Graz, Austria \\ *Corresponding author: Cesare Massone (cesare.massone@klinikum-graz.at) \\ FI000 Medicine Reports 2012, 4:II (doi:10.34I0/M4-II) \\ This is an open-access article distributed under the terms of the Creative Commons Attribution-Non Commercial License \\ (http://creativecommons.org/licenses/by-nc/3.0/legalcode), which permits unrestricted use, distribution, and reproduction in any medium, \\ provided the original work is properly cited. You may not use this work for commercial purposes. \\ The electronic version of this article is the complete one and can be found at: http://f1000.com/reports/m/4/I I
}

\begin{abstract}
Over the last 30 years dermatological approaches to diagnosis and management of melanocytic lesions have been revolutionized by the introduction of dermoscopy. Continuous improvements are being made in applying the technique, mostly in melanoma diagnosis, follow-up of melanocytic lesions and nevogenesis. Identification of new dermoscopic criteria, such as the dermoscopic island and the blue-black color for thin and nodular melanoma, respectively, further add two new weapons in the dermoscopical armamentarium for diagnosis of otherwise featureless melanoma. Recent advances show that short-term, 3-month, follow-up is the optimum time interval to identify minimal changes in initially featureless melanomas. Nevertheless, long-term follow-up is still useful for the recognition of changes in melanomas with a very low-rate of growth. Dermoscopy greatly improves diagnosis and early excision of melanomas and reduces the number of unnecessary excisions.
\end{abstract}

\section{Introduction}

In the pre-dermoscopic era, melanoma diagnosis was based only on clinical morphology and on the simple "ABCD" rule (asymmetry, border irregularity, color, diameter) $[1,2]$. Dermoscopy or dermatoscopy $[3,4]$ is a non-invasive technique that consists of viewing pigmented skin lesions through a hand-held lens, a dermatoscope or a video imaging system [5]. This procedure allows physicians to observe structures and colors not otherwise visible to the unaided eye, increasing melanoma diagnostic accuracy by up to $35 \%[3,6,7]$. The conventional dermoscopic diagnosis is based on the assessment of specific criteria and on the application of different diagnostic algorithms [5]. In recent years, polarized light dermatoscopes gradually overtook non-polarized light devices, which were introduced in the 1990s and are still used today [8].

Since its introduction in the mid-1980s, and thanks to more than 1500 publications, dermoscopy has developed and dramatically become a well-established, routine technique in many European countries and Australia
$[9,10]$. Nevertheless, in other countries, like the United States, dermoscopy still struggles to be accepted in daily clinical practice [11]. Herein, we reviewed the most recent important advances in dermoscopy of melanocytic lesions published in the last three years in English literature. Other applications of dermoscopy for non-melanoma skin cancers and other skin conditions are beyond the scope of this review $[6,12,13]$.

\section{New advances in melanoma diagnostics}

First, dermoscopy is not too time-consuming. The time for dermoscopic examination of nevi is basically double that required for a naked-eye examination (142 vs 70 seconds), but still under 3 minutes - a reasonable time for a correct skin cancer screening [14].

Dermoscopy reduces the number of unnecessary excisions $[3,15,16]$, thanks to the improvement of diagnostic accuracy [3]. Argenziano et al. showed that, in specialized clinical settings, the introduction of dermoscopy leads to a reduction of excised nevi and to an increased number of diagnosed and excised melanomas [16]. With 
dermoscopy, non-specialist clinicians are able to improve the malignant/benign ratio of excised lesions $[15,17]$ and even non-clinicians can identify suspicious lesions [18] simply by applying a simple method like the AC rule (asymmetry and color variation) [19].

Recently, several groups analyzed the most commonly used dermoscopic algorithms $[7,20,21]$. Haenssle et al. [7] and others [22] revised the 7-point checklist in a 10-year prospective study and found this method highly specific but less sensitive. In fact, 38\% of melanomas scored less than 3 points (in situ melanomas frequently only scored 1 point) using the checklist and were identified only thanks to additional information such as anamnestic data, the ugly-duckling sign and signature nevi $[7,23]$ or changes at digital follow-up [24]. Regression patterns, atypical vascular patterns and radial streaming were associated with the highest relative risk for melanoma [7]. Argenziano et al. revised the 7-point checklist, reducing the original 3-point threshold to 1-point in order to identify more melanomas. This gave higher mean rates of excision with an increased sensitivity but a lower specificity compared with the original 7-point checklist and pattern analysis. The authors recommend using the revised algorithm in a daily clinical setting, integrating dermoscopy with clinical information and follow-up [20].

Borsari et al. recently described a new melanoma predictor, the dermoscopic island [25], which differs from the eccentric pigmentation described by Arevalo et al. [26]. The dermoscopic island is defined as a circumscribed area showing a different dermoscopic pattern from the rest of the lesion (reticular, globular, homogeneous or starburst pattern) located at the periphery or in a paracentral position. It is more frequently observed in in situ and thin melanomas than in nevi, and represents the morphological aspect of initial malignant transformation. Lesions showing this feature should be referred for excision [25]. Eccentric pigmentation represents an area of asymmetrical pigment distribution and lesions showing this feature, but lacking other specific criteria for melanoma, do not require closer follow-up than other nevi [26].

The use of polarized light in dermoscopy allows the recognition of some structures not visible with nonpolarized light $[8,27,28]$. Shiny white streaks arranged in an orthogonal organization are known as chrysalis structures $[29,30]$. Some authors proposed changing this term to crystalline structures, to include short white lines, white strands, white clods or white areas and rosettes [31]. Short white lines arranged in an orthogonal fashion may be observed not just in melanomas and Spitz nevi but also in basal cell carcinomas, squamous cell carcinomas and dermatofibromas $[29,31,32]$.
Argenziano et al. [33] described a new predictor of nodular melanoma, the blue-black color due to the combination of pigment localized in the mid-deep dermis (blue) and, in atypical melanocytes, in the epidermis (black). The authors found a higher sensitivity for blue-black color with respect to standard criteria in the diagnosis of nodular melanoma (78.2\% vs $43.6 \%$ respectively). Combination of the two reaches $84.6 \%$ sensitivity with $80.5 \%$ specificity. The blueblack color is a useful new feature allowing the diagnosis of some melanomas lacking standard criteria.

Few studies have been performed on hypopigmented lesions. Menzies et al. [34] looked at hypomelanotic and amelanotic melanoma and found blue-white veil, scar-like depigmentation, multiple blue-gray dots, irregular-shaped depigmentation, brown dots/globules irregular in size or distribution, five to six colors and predominant central vessels to be the most positive predictors of melanoma. In contrast, three or more milia-like cysts, comma vessels with regular distribution or the predominant vessel type, symmetrical pigment distribution, irregular or multiple blue-gray globules are the most significant negative predictive factors in melanoma diagnosis [34]. Accuracy of dermoscopic criteria is lower for hypomelanoticamelanotic melanoma than with pigmented melanoma, but still superior to naked-eye examination [34].

\section{Advances in digital follow-up}

Sequential digital dermoscopy imaging (SDDI) is crucial in identifying melanomas lacking the specific criteria of malignancy. Unlike long-term follow-up (6-12 months), any morphologic change detected on short-term 3-month follow-up serves as a reliable prompt for the physician to excise the lesion. In contrast, lesions not showing dermoscopic changes on follow-up imaging can be left to avoid unnecessary excision $[24,35,36]$. Three-month followup remains the correct interval (rather than 6 weeks) to diagnose featureless melanoma [35]. Three months is also the recommended follow-up period for high-risk patients, such as those with familial atypical mole and multiple melanoma (FAMMM) syndrome, but 6-12 months is better for those with atypical mole syndrome $[37,38]$.

Short-term follow-up is also the best strategy to optimize patient compliance. Patients addressed to a short-term follow-up are more likely to return compared with longterm follow-up patients, probably because of the major concern about a lesion to be checked after only 3 months [36]. Unfortunately, not all melanomas are clearly detected at 3-months follow-up. Sometimes long-term follow-up visits are needed to detect suspect changes [39].

Argenziano et al. [39] described a series of 103 melanomas diagnosed and excised after long-term follow-up with 
minimal dermoscopic changes, with respect to the baseline visit (mean follow-up time: 20 months) and still in situ or thin at the time of histopathological diagnosis. Melanomas showing a reticular pattern on baseline image are more likely to remain in situ, whereas those with a nonreticular pattern usually show major changes at follow-up control. This supports the theory that melanoma represent a family of tumors: rapidly growing melanomas with a high capacity to metastasize, on the one hand, and slowly growing lesions often detectable only after repeated follow-up visits, on the other. Correct use of SDDI allows us to increase diagnostic accuracy, and reduce the number of undetected melanomas and also unnecessary excisions [24,38].

\section{Advances in understanding melanocytic nevi and nevogenesis}

Dermoscopy also allows us to study the physiology of nevi (clusters of pigmented skin cells). Some people have a high propensity to develop nevi, others lower, and this propensity is genetically established and, in part, due to environmental factors. The number of nevi is small in childhood, increases during adolescence and mid-life, and finally decreases during late adulthood [40-42]. The dermoscopic pattern of nevi seems to be age- and siterelated, with a prevalence of globular nevi on the trunk in childhood (which tend to persist), and reticular nevi appearing on the upper back and extremities in adulthood (which tend to fade over time) $[40,41,43,44]$.

These data led Zalaudek et al. to prepare two different pathways for nevogenesis $[40,45]$ : the constitutional pathway gives rise to congenital globular nevi in childhood; and the acquired pathway is responsible for arising nevi with a prevalent reticular pattern in adolescence and adulthood. Based on these and other observations, Argenziano et al. proposed a new dermoscopic classification of melanocytic nevi into seven groups based on specific dermoscopic features that identify those lesions as specific entities (Table 1) [46].

Spitz/Reed nevi received particular attention. The original clinical description of a pink-red papulonodular lesions on the face and extremities of children or black (Reed nevus) papules or plaques on the extremities is no longer optimal for diagnosis $[47,48]$. Dermoscopy completely changed this view by identifying three main dermoscopic patterns: globular, starburst and multicomponent (atypical, melanoma-like) $[48,49]$. Similar to acquired nevi, Spitz/Reed nevi follow an evolution/involution process [50]. In the evolution, or growing phase, Spitz/Reed nevi show the classical starburst pattern, which is subsequently replaced after a variable number of months by a homogenous pattern observed during the stability phase. After some years, lesions gradually lose pigment and finally disappear, indicating that involution is common [50]. However, the recommendation is to excise nevi with spitzoid features in patients older than 12 years [48].

The BRAF oncogene is highly expressed in acquired nevi, whereas other types of melanocytic nevi - such as congenital dermal nevi, Spitz, and blue nevi - are usually characterized by mutations in other genes. BRAF mutations induce melanocyte proliferation, forming neoplastic

Table I. Nevus dermoscopic subtypes

\begin{tabular}{|c|c|c|}
\hline Nevus type & Clinical features & Dermoscopic features \\
\hline Globular (congenital) nevus & $\begin{array}{l}\text { Present at birth or appearing before } \\
\text { puberty }\end{array}$ & Globular pattern in children; cobblestone or fried-egg pattern in adults \\
\hline Reticular (acquired) nevus & Onset after puberty or in adulthood & $\begin{array}{l}\text { Reticular pattern with or without hypopigmented or structureless area. } \\
\text { Occasionally atypical features }\end{array}$ \\
\hline Starburst (Spitz/Reed) nevus & $\begin{array}{l}\text { Onset mostly during childhood or } \\
\text { adolescence }\end{array}$ & $\begin{array}{l}\text { Peripheral pigmented streaks or globules symmetrically distributed. Dotted } \\
\text { vessels and reticular depigmentation in non-pigmented lesions }\end{array}$ \\
\hline Blue (homogeneous) nevus & Congenital or acquired & $\begin{array}{l}\text { Homogeneous structureless blue coloration. Sometimes white areas of fibrosis } \\
\text { or hypomelanosis }\end{array}$ \\
\hline \multicolumn{3}{|r|}{ (1) } \\
\hline a. Acral nevus & Congenital or acquired & Parallel furrow, lattice-like, fibrillar pattern and other minor patterns \\
\hline b. Facial nevus & Congenital or early-acquired & $\begin{array}{l}\text { Children: pseudoreticular pattern } \\
\text { Adults: remnants of pigmentation and comma vessels }\end{array}$ \\
\hline \multicolumn{3}{|l|}{ Nevi with special features } \\
\hline a. Combined nevus & Congenital or acquired & $\begin{array}{l}\text { Combination of two or more patterns: reticular, globular, homogeneous and } \\
\text { starburst }\end{array}$ \\
\hline b. Halo nevus & Congenital or acquired & Globular pattern with blue granules and/or with scar-like areas \\
\hline c. Irritated nevus & Congenital or acquired & Reticular, globular or structureless with variable grey or red areas \\
\hline d. Nevus with eczematous halo & Congenital or acquired & Reticular, globular or structureless with yellowish areas \\
\hline c. Recurrent nevus & $\begin{array}{l}\text { Congenital or acquired (previous } \\
\text { excision or trauma) }\end{array}$ & Atypical pigmentation and scar-like areas \\
\hline $\begin{array}{l}\text { Unclassifiable melanocytic } \\
\text { lesions }\end{array}$ & $\begin{array}{l}\text { One of the previous nevi with } \\
\text { atypical features }\end{array}$ & $\begin{array}{l}\text { One of the previous patterns with atypical features. Melanoma cannot be } \\
\text { ruled out }\end{array}$ \\
\hline
\end{tabular}


clones. Without any other genetic alteration, such as that induced by intermittent UV exposure, proliferation stops and cells enter a senescent phase [40]. BRAF mutations are probably acquired early in nevogenesis and their level of expression is correlated with the phase of growth [51]. Based on this theory, it seems that young benign reticular nevi express high levels of BRAF mutations, slowly decreasing with nevus growth, followed by a final low rate in senescence [40].

\section{Conclusions}

Dermoscopy has dramatically improved the diagnostic accuracy of melanocytic skin lesions and, more recently, is helping us understand nevogenesis mechanisms and nevus physiology. New advances in terms of optimal application and follow-up and newly described criteria have gradually allowed us to correctly diagnose melanoma even in very early stages, where rates of curability and survival are high. This success may be an argument for a more widespread application of dermoscopy to screen the wider asymptomatic community on a routine basis.

\section{Abbreviations}

FAMMM, familial atypical mole and multiple melanoma; SDDI, sequential digital dermoscopy imaging.

\section{Competing interests}

The authors declare that they have no competing interests.

\section{References}

I. Friedman RJ, Rigel DS, Kopf AW: Early detection of malignant melanoma: the role of physician examination and selfexamination of the skin. CA Cancer J Clin 1985, 35:|30-5I.

2. Rigel DS, Friedman RJ: The rationale of the $\mathbf{A B C D}$ s of early melanoma. J Am Acad Dermatol 1993, 29:1060-I.

3. Vestergaard ME, Macaskill P, Holt PE, Menzies SW: Dermoscopy compared with naked eye examination for the diagnosis of primary melanoma: a meta-analysis of studies performed in a clinical setting. $\mathrm{Br} J$ Dermatol 2008, I 59:669-76.

FI000 Factor 6

Evaluated by Giuseppe Argenziano and Elvira Moscarella 06 Nov 2009

4. Malvehy J, Puig S, Argenziano G, Marghoob AA, Soyer HP: Dermoscopy report: proposal for standardization. Results of a consensus meeting of the International Dermoscopy Society. International Dermoscopy Society Board members. J Am Acad Dermatol 2007, 57:84-95.

5. Massone C, Di Stefani A, Soyer HP: Dermoscopy for skin cancer detection. Curr Opin Oncol 2005, 17:147-53.

6. Braun RP, Oliviero M, Kolm I, French LE, Marghoob AA, Rabinovitz H: Dermoscopy: what's new? Clin Dermatol 2009, 27:26-34.

7. Haenssle HA, Korpas B, Hansen-Hagge C, Buhl T, Kaune KM, Rosenberger A, Krueger U, Schon MP, Emmert S: Seven-point checklist for dermatoscopy: Performance during 10 years of prospective surveillance of patients at increased melanoma risk. J Am Acad Dermatol 2010, 62:785-93.

FI000 Factor 7

Evaluated by Giuseppe Argenziano and Elvira Moscarella 09 Nov 2010, Cesare Massone 18 May 2012

8. Wang SQ, Dusza SW, Scope A, Braun RP, Kopf AW, Marghoob AA: Differences in dermoscopic images from nonpolarized dermoscope and polarized dermoscope influence the diagnostic accuracy and confidence level: a pilot study. Dermatol Surg 2008, 34:1389-95.

FI000 Factor 6

Evaluated by Cesare Massone 18 May 2012

9. Tasli L, Kaçar N, Argenziano G: A scientometric analysis of dermoscopy literature over the past 25 years. J Eur Acad Dermatol Venereol, [Epub ahead of print].

10. Venugopal SS, Soyer HP, Menzies SW: Results of a nationwide dermoscopy survey investigating the prevalence, advantages and disadvantages of dermoscopy use among Australian dermatologists. Australas J Dermatol 201 I, 52:14-8.

FI000 Factor 6

Evaluated by Cesare Massone 18 May 2012

II. Engasser HC, Warshaw EM: Dermatoscopy use by US dermatologists: a cross-sectional survey. J Am Acad Dermatol 2010, 63:4I 2-9.

FI000 Factor 6

Evaluated by Cesare Massone 18 May 2012

12. Zalaudek I, Kreusch J, Giacomel J, Ferrara G, Catricalà C, Argenziano G: How to diagnose nonpigmented skin tumors: a review of vascular structures seen with dermoscopy: part II. Nonmelanocytic skin tumors. J Am Acad Dermatol 2010, 63: 377-86; quiz 387-8.

FI000 Factor 6

Evaluated by Cesare Massone 18 May 2012

13. Mogensen M, Jemec GB: Diagnosis of nonmelanoma skin cancer/ keratinocyte carcinoma: a review of diagnostic accuracy of nonmelanoma skin cancer diagnostic tests and technologies. Dermatol Surg 2007, 33:1 I58-74.

14. Zalaudek I, Kittler H, Marghoob AA, Balato A, Blum A, Dalle S, Ferrara G, Fink-Puches R, Giorgio CM, Hofmann-Wellenhof R, Malvehy J, Moscarella E, Puig S, Scalvenzi M, Thomas L, Argenziano $G$ : Time required for a complete skin examination with and without dermoscopy: a prospective, randomized multicenter study. Arch Dermatol 2008, 144:509-13.

FI000 Factor 6

Evaluated by Cesare Massone 18 May 2012

15. van der Rhee Jl, Bergman W, Kukutsch NA: The impact of dermoscopy on the management of pigmented lesions in everyday clinical practice of general dermatologists: a prospective study. Br J Dermatol 2010, 162:563-7.

FI000 Factor 6

Evaluated by Cesare Massone 18 May 2012

16. Argenziano G, Cerroni L, Zalaudek I, Staibano S, HofmannWellenhof R, Arpaia N, Bakos RM, Balme B, Bandic J, Bandelloni R, Brunasso AM, Cabo H, Calcara DA, Carlos-Ortega B, Carvalho AC, Casas G, Dong H, Ferrara G, Filotico R, Gómez G, Halpern A, Ilardi G, Ishiko A, Kandiloglu G, Kawasaki H, Kobayashi K, Koga H, Kovalyshyn I, Langford D, Liu X, Marghoob AA, Mascolo M, Massone C, Mazzoni L, Menzies S, Minagawa A, Nugnes L, Ozdemir F, Pellacani G, Seidenari S, Siamas K, Stanganelli I, Stoecker WV, Tanaka M, Thomas L, Tschandl P, Kittler H: Accuracy in melanoma detection: A I0-year multicenter survey. J Am Acad Dermatol 20I I, [Epub ahead of print]. 
17. Terushkin V, Warycha M, Levy M, Kopf AW, Cohen DE, Polsky D: Analysis of the benign to malignant ratio of lesions biopsied by a general dermatologist before and after the adoption of dermoscopy. Arch Dermatol 20I0, I46:343-4.

FI000 Factor 6

Evaluated by Cesare Massone 18 May 2012

18. Goulart JM, Malvehy J, Puig S, Martin G, Marghoob AA: Dermoscopy in skin self-examination: $A$ useful tool for select patients. Arch Dermatol 20II, 147:53-8.

FI000 Factor 9

Evaluated by H Peter Soyer and Nicola Douglas 04 May 201I, Cesare Massone 18 May 2012

19. Luttrell MJ, Hofmann-Wellenhof R, Fink-Puches R, Soyer HP: The AC Rule for melanoma: A simpler tool for the wider community. J Am Acad Dermatol 20II, 65:1233-4.

FI000 Factor 6

Evaluated by Cesare Massone 18 May 2012

20. Argenziano G, Catricalà $C$, Ardigo $M$, Buccini $P$, De Simone $P$, Eibenschutz L, Ferrari A, Mariani G, Silipo V, Sperduti I, Zalaudek I: Seven-point checklist of dermoscopy revisited. $\mathrm{Br} J$ Dermatol 2011, 164:785-90.

\section{FI000 Factor 9}

Evaluated by Iria Neri and Riccardo Balestri 06 Feb 2012, Cesare Massone 18 May 2012

21. Marghoob AA, Braun R: Proposal for a revised 2-step algorithm for the classification of lesions of the skin using dermoscopy. Arch Dermatol 2010, 146:426-8.

FI000 Factor 6

Evaluated by Cesare Massone 18 May 2012

22. Argenziano G, Fabbrocini G, Carli P, De Giorgi V, Sammarco E, Delfino M: Epiluminescence microscopy for the diagnosis of doubtful melanocytic skin lesions. Comparison of the ABCD rule of dermatoscopy and a new 7-point checklist based on pattern analysis. Arch Dermatol 1998, 134:1563-70.

FI000 Factor 6

Evaluated by Cesare Massone 18 May 2012

23. Suh KY, Bolognia JL: Signature nevi. J Am Acad Dermatol 2009, 60:508-14.

FI000 Factor 6

Evaluated by Cesare Massone 18 May 2012

24. Menzies SW, Emery J, Staples M, Davies S, McAvoy B, Fletcher J, Shahid KR, Reid G, Avramidis M, Ward AM, Burton RC, Elwood JM: Impact of dermoscopy and short-term sequential digital dermoscopy imaging for the management of pigmented lesions in primary care: a sequential intervention trial. $\mathrm{Br} J$ Dermatol 2009, 161:1270-7.

FI000 Factor 7

Evaluated by Giuseppe Argenziano and Elvira Moscarella 31 Mar 2010, Cesare Massone 18 May 2012

25. Borsari S, Longo C, Ferrari C, Benati E, Bassoli S, Schianchi S, Giusti F, Cesinaro AM, Pellacani G, Seidenari S: Dermoscopic island: a new descriptor for thin melanoma. Arch Dermatol 2010, I46: I257-62.

FI000 Factor 6

Evaluated by Cesare Massone 18 May 2012

26. Arevalo A, Altamura D, Avramidis M, Blum A, Menzies S: The significance of eccentric and central hyperpigmentation, multifocal hyper/hypopigmentation, and the multicomponent pattern in melanocytic lesions lacking specific dermoscopic features of melanoma. Arch Dermatol 2008, 144: 1440-4.

FI000 Factor 7

Evaluated by Giuseppe Argenziano and Elvira Moscarella 02 Feb 2009, Cesare Massone 18 May 2012

27. Benvenuto-Andrade C, Dusza SW, Agero AL, Scope A, Rajadhyaksha M, Halpern AC, Marghoob AA: Differences between polarized light dermoscopy and immersion contact dermoscopy for the evaluation of skin lesions. Arch Dermatol 2007, 143:329-38.

FI000 Factor 6

Evaluated by Cesare Massone 18 May 2012

28. Pan Y, Gareau DS, Scope A, Rajadhyaksha M, Mullani NA, Marghoob AA: Polarized and nonpolarized dermoscopy: the explanation for the observed differences. Arch Dermatol 2008, I 44:828-9.

FI000 Factor 6

Evaluated by Cesare Massone 18 May 2012

29. Marghoob AA, Cowell L, Kopf AW, Scope A: Observation of chrysalis structures with polarized dermoscopy. Arch Dermatol 2009, 145:618.

30. Di Stefani A, Campbell TM, Malvehy J, Massone C, Soyer HP, Hofmann-Wellenhof R: Shiny white streaks: an additional dermoscopic finding in melanomas viewed using contact polarised dermoscopy. Australas J Dermatol 2010, 5 I:295-8.

31. Liebman TN, Rabinovitz HS, Dusza SW, Marghoob AA: White shiny structures: dermoscopic features revealed under polarized light. J Eur Acad Dermatol Venereol, [Epub ahead of print].

FI000 Factor 6

Evaluated by Cesare Massone 18 May 2012

32. Balagula Y, Braun RP, Rabinovitz HS, Dusza SW, Scope A, Liebman TN, Mordente I, Siamas K, Marghoob AA: The significance of crystalline/chrysalis structures in the diagnosis of melanocytic and nonmelanocytic lesions. J Am Acad Dermatol, [Epub ahead of print].

33. Argenziano G, Longo C, Cameron A, Cavicchini S, Gourhant JY, Lallas A, McColl I, Rosendahl C, Thomas L, Tiodorovic-Zivkovic D, Zaballos P, Zalaudek I: Blue-black rule: a simple dermoscopic clue to recognize pigmented nodular melanoma. $\mathrm{Br}$ J Dermatol 20II, 165:125I-5.

FI000 Factor 6

Evaluated by Cesare Massone 18 May 2012

34. Menzies SW, Kreusch J, Byth K, Pizzichetta MA, Marghoob A, Braun R, Malvehy J, Puig S, Argenziano G, Zalaudek I, Rabinovitz HS, Oliviero M, Cabo H, Ahlgrimm-Siess V, Avramidis M, Guitera P, Soyer HP, Ghigliotti G, Tanaka M, Perusquia AM, Pagnanelli G, Bono R, Thomas L, Pellacani G, Langford D, Piccolo D, Terstappen K, Stanganelli I, Llambrich A, Johr R: Dermoscopic evaluation of amelanotic and hypomelanotic melanoma. Arch Dermatol 2008, 144: I I 20-7.

FI000 Factor 6

Evaluated by Cesare Massone 18 May 2012

35. Altamura D, Avramidis M, Menzies SW: Assessment of the optimal interval for and sensitivity of short-term sequential digital dermoscopy monitoring for the diagnosis of melanoma. Arch Dermatol 2008, 144:502-6.

FI000 Factor 6

Evaluated by Cesare Massone 18 May 2012

36. Argenziano G, Mordente I, Ferrara G, Sgambato A, Annese P, Zalaudek I: Dermoscopic monitoring of melanocytic skin 
lesions: clinical outcome and patient compliance vary according to follow-up protocols. Br J Dermatol 2008, I59:33 I-6.

FI000 Factor 6

Evaluated by Cesare Massone 18 May 2012

37. Haenssle HA, Korpas B, Hansen-Hagge C, Buhl T, Kaune KM, Johnsen S, Rosenberger A, Schön MP, Emmert S: Selection of patients for long-term surveillance with digital dermoscopy by assessment of melanoma risk factors. Arch Dermatol 2010, | 46:257-64.

FI000 Factor 6

Evaluated by Cesare Massone 18 May 2012

38. van der Rhee JI, Bergman W, Kukutsch NA: Impact of dermoscopy on the management of high-risk patients from melanoma families: a prospective study. Acta Derm Venereol 20I I, 91:428-3I.

FI000 Factor 6

Evaluated by Cesare Massone 18 May 2012

39. Argenziano G, Kittler H, Ferrara G, Rubegni P, Malvehy J, Puig S, Cowell L, Stanganelli I, De Giorgi V, Thomas L, Bahadoran P, Menzies SW, Piccolo D, Marghoob AA, Zalaudek I: Slow-growing melanoma: a dermoscopy follow-up study. Br J Dermatol 2010, I 62:267-73.

FI000 Factor 6

Evaluated by Cesare Massone 18 May 2012

40. Zalaudek I, Catricalà C, Moscarella E, Argenziano G: What dermoscopy tells us about nevogenesis. J Dermatol 2011, 38:16-24.

41. Scope A, Marghoob AA, Dusza SW, Satagopan JM, Agero AL, Benvenuto-Andrade C, Lieb JA, Weinstock MA, Oliveria SA, Geller AC, Halpern AC: Dermoscopic patterns of naevi in fifth grade children of the Framingham school system. $\mathrm{Br} J$ Dermatol 2008, I58:1041-9.

FI000 Factor 6

Evaluated by Cesare Massone 18 May 2012

42. Terushkin V, Scope A, Halpern AC, Marghoob AA: Pathways to involution of nevi: insights from dermoscopic follow-up. Arch Dermatol 2010, I46:459-60.

43. Scope A, Dusza SW, Marghoob AA, Satagopan JM, Braga Casagrande Tavoloni J, Psaty EL, Weinstock MA, Oliveria SA, Bishop M, Geller AC, Halpern AC: Clinical and dermoscopic stability and volatility of melanocytic nevi in a population-based cohort of children in Framingham school system. J Invest Dermatol 201 I, |31:|6|5-2|.

FI000 Factor 9

Evaluated by H Peter Soyer and Nicola Douglas I4 Jun 20 I I, Cesare

Massone 18 May 2012
44. Zalaudek I, Schmid K, Marghoob AA, Scope A, Manzo M, Moscarella E, Malvehy J, Puig S, Pellacani G, Thomas L, Catricalà C, Argenziano G: Frequency of dermoscopic nevus subtypes by age and body site: a cross-sectional study. Arch Dermatol 20I I, I47:663-70.

FI000 Factor 6

Evaluated by Cesare Massone 18 May 2012

45. Zalaudek I, Leinweber B, Hofmann-Wellenhof $R$, Scope A, Marghoob AA, Ferrara G, Pellacani G, Argenziano G, Soyer HP: The epidermal and dermal origin of melanocytic tumors: theoretical considerations based on epidemiologic, clinical, and histopathologic findings. Am J Dermatopathol 2008, 30:403-6.

FI000 Factor 6

Evaluated by Cesare Massone 18 May 2012

46. Argenziano G, Zalaudek I, Ferrara G, Hofmann-Wellenhof R, Soyer HP: Proposal of a new classification system for melanocytic naevi. Br J Dermatol 2007, 157:217-27.

FI000 Factor 6

Evaluated by Cesare Massone 18 May 2012

47. Requena C, Requena L, Kutzner H, Sánchez Yus E: Spitz nevus: a clinicopathological study of 349 cases. Am J Dermatopathol 2009, 3 1: 107-16.

48. Ferrara G, Zalaudek I, Argenziano G: Spitz nevus: an evolving clinicopathologic concept. Am J Dermatopathol 2010, 32:4l0-4.

FI000 Factor 6

Evaluated by Cesare Massone 18 May 2012

49. Ferrara G, Zalaudek I, Savarese I, Scalvenzi M, Argenziano G: Pediatric atypical spitzoid neoplasms: a review with emphasis on 'red' ('spitz') tumors and 'blue' ('blitz') tumors. Dermatology 2010, 220:306-10.

FI000 Factor 9

Evaluated by Debora Cadore de Farias, Marina Besen Guerini and Naiana Bittencourt de Sá 0I Nov 2010, Cesare Massone 18 May 2012

50. Argenziano G, Agozzino M, Bonifazi E, Broganelli P, Brunetti B, Ferrara G, Fulgione E, Garrone A, Zalaudek I: Natural evolution of Spitz nevi. Dermatology 201 I, 222:256-60.

FI000 Factor 6

Evaluated by Cesare Massone 18 May 2012

5I. Zalaudek I, Guelly C, Pellacani G, Hofmann-Wellenhof R, Trajanoski S, Kittler H, Scope A, Marghoob AA, Longo C, Leinweber B, Ferrara G, Saida T, Grichnik JM, Argenziano G, Becker JC: The dermoscopical and histopathological patterns of nevi correlate with the frequency of BRAF mutations. J Invest Dermatol 201 I, I 3 I:542-5.

FI000 Factor 6

Evaluated by Cesare Massone 18 May 2012 